\title{
Comparative Analysis of Personnel Distributions in the Local Government Service in Ekiti-State, Nigeria, for Service Delivery
}

\author{
Olaniyan Joseph Olawale ${ }^{\text {a }}$, Ademuyiwa A. Justus ${ }^{\text {b }}$ \\ ${ }^{a}$ Department of Mathematics and Statistics, Federal Polytechnic Ado-Ekiti, Ado-Ekiti, 360231, Nigeria \\ ${ }^{b}$ Department of Statistics, Federal Polytechnic Ile-Oluji, Ile-Oluji, 3751110, Nigeria
}

Received: 15 March 2017; Accepted: 13 February 2019; Published: 08 April 2019

\begin{abstract}
It's is no longer news that the Local Government (Third-tier of government in Nigeria) has not been able to optimally discharge its responsibilities according to its mandate. This had raised serious policy and research concerns that resulted to several reformative approaches in a bid to restructuring the system for efficient service delivery in the past decade. One major unpopular reason for inefficient service delivery was poor administration in the Local Government as a result of unbalanced distribution of personnel by cadre and gender in each local government in the state. This had not only hampered local government administration but also impeded adequate provision of expected services to local populace in line with its mandate as enshrined in the fourth schedule of the 1999 Constitution of the Federal Republic of Nigeria. Application of Statistical analysis using Chi-square Test of Independence showed that distribution of employees by cadre depends on local government in post in the year under study. Percentage distributions employed revealed that some local governments that are located around the capital city had more workers than those located outside the state capital city except some local governments with more viable socio-economic benefits. Sex ratio showed that there was gender imbalance as female personnel are more than their male counterpart in the local government service is.
\end{abstract}

Index Terms: Personnel Distribution, Personnel, Service Delivery, Local Government Service, Cadre, Grade Level, Gender.

(C) 2019 Published by MECS Publisher. Selection and/or peer review under responsibility of the Research Association of Modern Education and Computer Science

\section{Introduction}

The Local Government, popularly, regarded as the "third-tier" of government in Nigeria (Local Government *Corresponding author. Olaniyan Joseph Olawale. Tel.: 08035183138;

E-mail Address: olawalelink2007@yahoo.com 
Reforms, 1976.), has been in existence since colonial era, and has undergone various reforms in terms of names, structure and composition (Aleyomi, 2013:36). It will be recalled that the essence of having the third-tier of government in Nigeria was to have a replicate of democratic norms, political participation, protective services, provision of basic amenities etc. as it were in the other two tiers of Government namely, State and Federal Government. Government at local level was established by law to exercise specific powers within defined areas, determine and implement projects so as to complement the activities of the state and federal government in their areas (Local Government Reforms, 1976). This political sub-division of a nation has substantial but limited control over its local affairs including the power to impose taxes or other forms of generating revenue for provision of services and to draw labour for pre-designed purposes (Fourth schedule, 1999 constitution of the Federal Republic of Nigeria).

Ekiti state, the focus of this study, was created on October $\mathbf{1}^{\text {st }}, 1996$ by the General Sani Abacha's regime with sixteen Local Government Areas namely; Ado, Efon Alaaye, Ekiti East, Ekiti South West, Ekiti West, Emure, Gbonyin, Ido/Osi, Ijero, Ikere, Ikole, Ilejemeje, Irepodun/ Ifelodun, Ise/Orun, Moba and Oye Local Government Areas (First Schedule, Part 1, 1999 constitution of the Federal Republic of Nigeria). In practice, Local Government draws its major personnel from its locality to aid formulation and implementation of its programmes. It's obvious that no government can achieve its goals if its workforce is not properly and objectively coordinated to carry out their prescribed responsibilities. The recruitment, promotion, conditions of service, discipline, as well as deployment of workers to various duty posts through transfer and posting (Management of Human Resource) in the Ekiti State Local Government service is principally coordinated by the Local Government Service Commission (LGSC), a major Agency in-charge of work-force management in the Local Government service in Nigeria.

Local government service commission was established by the law of the Federal Republic of Nigeria (Third Schedule Part IIB, 1999 Constitution of Federal Republic of Nigeria) and headed by a Chairman and not less than two and not more than four members to oversee staff matters in order to guarantee efficiency and effectiveness of personnel in Local Government Councils in the federation. The state government uses the commission to regulate Local Government programmes, by deploying competent calibre of staff to the Local Government Councils, resulting in improved implementation of democratic policies of the councils. There are two categories of workers in the local government service in Ekiti state, namely: Unified staff (Grade Level: 07-17) and Non-unified staff (Grade Level: 01-06). Matters affecting non-unified staff are under the purview of each Local Government Authority, while Local Government Service Commission regulates unified category including advancement and absorption of non-unified staff to unified cadre as long as requisite conditions are met by the applicants.

Typically, promotion, appointment and exit from service are precursors to allocation or deployment of employees to various Local Governments in the state. For efficient productivity, employees are supposed to be regularly distributed, cadre by cadre and gender by gender in all departments in the local government councils. Distributions of workers through posting helps to enrich workers experience thereby add more values to their productivity. According to investigation, the last promotion for Local Government workers in the state was in 2013; hence, major posting was only done in 2014. However, other posting was carried out in 2015 but not substantial enough to create any significant effect on the results of this study. There are 7 departments within which workers are being distributed in the local government according to their field and designation. The departments are; Administration, Agriculture and Natural Resources Development, Budget, Planning Research and Statistics, Community Development, Finance, Primary Health Care and Works departments (1999 Local Government Scheme of Service).

It is common in the Local Government system that some workers have developed the habit of dishonouring posting, thereby resulting in hanging longer than necessary in a particular duty post for one reason or the other. While some who were not comfortable wherever posted quickly hunted for immediate redeployment. There were occasions where important cadres like Accountant, Statistician etc. were over-staffed in some Local Government Councils while other Councils were not enough or not available thereby overloading the little 
available ones or replacing the officers by non-substantive officers. Some reasons such as proximity to residence, juicy stations, unionism and other associations like cooperative societies among others were responsible for the abnormality in the distribution of workers. This is therefore the reason for this study.

The Objectives of this study are outlined as follows:

- To compare the distribution of personnel by Local Government Council

- To compare distribution of personnel by gender with and without regard to grade levels

- To examine whether or not the distribution of personnel by grade level is independent of the Local Government Council in post.

\subsection{Materials and Methods}

The data used in this study was transcribed from the records of the Bureau of Statistics, Ekiti State, on distribution of personnel statistics by cadre and gender in relation to local government Councils in post in the year 2014. Statistical analysis using Percentage Distribution, bar chart, Sex Ratio and Pearson's Chi-Square Test of independence, were used to analyse the data.

\section{Sex Ratio}

This is a demographic index that measures the number of males per 100 females in a population. It relates the proportion of males to females. A sex ratio with a value of more than 100 indicates the excess of male over female while a value less than 100 means shortage of male over female. Sex ratio is mathematically expressed as;

Sex ratio $=\frac{\text { Number of males }}{\text { Number of females }} \times 100$

It indicates numerical equality or inequality between the sexes.

\subsection{Chi-Square Distribution}

In 1870, Chi-Square was first developed by Fisher and its properties were later investigated by Karl Pearson in 1900 in its modern form. The chi square distribution is a theoretical or mathematical distribution which has wide applicability in statistical work. The term 'chi square' (pronounced with a hard 'ch') is used because the Greek letter $x^{2}$ is used todefine this distribution. It will be seen that the elements on which this distribution is based are squared, so that the symbol $x^{2}$ is used to denote the distribution. The distribution of chi-square is expressed mathematically as;

$$
\mathrm{f}(\mathrm{y})=\frac{1}{\left(\frac{n}{2}-1\right) ! 2^{n / 2}} y^{(n / 2)^{-1}} e^{-y / 2} \quad \mathrm{y}>0
$$

From equation (2),

$$
\mathrm{y}=\sum_{i=1}^{n}\left(\frac{x_{1}-\mu_{i}}{\sigma_{i}}\right) \text {, and } \mathrm{e}=2.71828
$$

Though chi-square distribution is applied in both the test of independence and goodness of fit, only the test of independence is considered in this study. 


\subsection{Pearson's Chi-Square Test of Independence}

The Chi-Square $\left(\boldsymbol{x}^{2}\right)$ test for independence of two variables is a test which uses across-classification table to examine the nature of the relationship between these variables. These tables are sometimes referred to as contingency tables. The tables show the manner in which two variables are either or not related to each other. The test for independence examines whether the observed pattern between the variables in the table is strong enough to show that the two variables are dependent on each other or not.

The chi square test of independence is very general, and can be used with variables measured on any type of scale, nominal, ordinal, interval or ratio. The only limitation on the use of this test is that the sample sizes must be sufficiently large to ensure that the expected number of cases in each category is five or more. This rule can be modified somewhat, but as with all approximations, larger sample sizes are preferable to smaller sample sizes. The chi square test for independence is conducted by assuming that there is independence between the two variables being examined $\left(\mathrm{H}_{\mathrm{O}}\right)$. The alternative hypothesis, $\mathrm{H}_{\mathrm{I}}$, is that there is no independence between the variables. This can be stated as;

$\boldsymbol{H}_{\mathbf{0}}$ : Independence between the two variables

$\boldsymbol{H}_{1}$ : No independence between the two variables

The $\boldsymbol{x}^{2}$ can be calculated from the expression;

$$
x^{2}=\sum_{1}^{r} \sum_{1}^{c}\left(\frac{\left(O_{i j-} E_{i j}\right)^{2}}{E_{i j}}\right)
$$

where,

$O_{i j}$ is the observed value in the ith row, jth column; $E_{i j}$ is the expected value in the ith row, jth column. While $\mathrm{r}$ is the row and $\mathrm{c}$ is the column of the contingency tables. The result obtained on $\boldsymbol{x}^{2}$ is compared to table value of $\boldsymbol{x}^{2}{ }_{(\boldsymbol{r}-1)(\boldsymbol{c}-1), \boldsymbol{\alpha}}$; where, $(\mathrm{r}-1)(\mathrm{c}-1)$ is the Degree of Freedom, DF, if $\mathrm{r}>1$ and $\mathrm{c}>1$. If $\mathrm{r}=1, \quad \mathrm{c}>1$, then $\mathrm{DF}=\mathrm{c}-1$ or if $\mathrm{r}>1$ and $\mathrm{c}=1$ and $\alpha$ is the significant level. Again, probability value can be used by comparing it to $\boldsymbol{\alpha}$, to decide whether to reject or not to reject the null hypothesis. If the probability value is smaller than $\boldsymbol{\alpha}$, the null Hypothesis will be rejected.

\section{Data Presentation and Analysis}

\subsection{Data Presentation}

The data obtained through transcription from the Ekiti State Bureau of Statistics; 'Digest of Local Government Statistics, 2014 is shown in the table below. It reflects personnel statistics by grade level and sex, against local governments in post in year 2014.

Considering Table 1 above, the percentage of ground total indicates that the highest percentage of personnel (7.73\%) was in Ekiti West local Government while the least percentage of personnel was in Ilejemeje local Government $(\mathbf{3 . 8 0} \%)$ on both grade level and gender. This shows that the range of percentage of the staff distribution was 3.93\%. It shows that the difference between the Local Governments with highest and least personnel was high. This implies discrimination in the distribution of personnel in the Local Governments. However, only $\mathbf{1 . 5 2 \%}$ of the total personnel were in the Local Government Agencies such as Local Government Service Commission, Loans Board, Pension Board and Training School. Local governments like Ekiti West (7.73\%), Gbonyin (7.44\%), Ikole (7.09\%) and Irepodun /Ifelodun (7.22\%) had larger percentages 
of personnel because of their proximity to the state capital, population advantage and other important factors. Ekiti East (7.60\%) was favoured with higher percentage of staff because of its high economic and social benefits as it's located at the state boundary with Kogi State. Ijero Local Governments $(\mathbf{6 . 7 3 \%})$ was favoured with high percentage of personnel because of its rich cultural heritage and other socio-economic benefits like population advantage and long time of creation, as it's one of the Local Governments inherited by Ekiti state. Efon-Alaaye and Ilejemeje had least percentage of staff because of their distances from the state capital (Ado Ekiti) and transportation inconveniences. Efon-Alaaye was one-town local government and didn't enjoy population advantage while Ilejemeje was a new local government created the same time with the creation of Ekiti State and not located along the major road.

Table 1. Personnel Statistics by Grade Level, Sex and Local Government in post

\begin{tabular}{|c|c|c|c|c|c|c|c|c|c|c|c|c|c|c|c|}
\hline \multirow{3}{*}{$\begin{array}{l}\text { LOCAL } \\
\text { GOVT }\end{array}$} & \multicolumn{10}{|c|}{ GRADE LEVEL } & & & \multirow{3}{*}{ 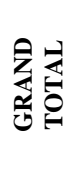 } & \multirow{3}{*}{ 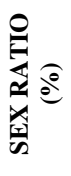 } & \multirow{3}{*}{ ن } \\
\hline & \multicolumn{2}{|c|}{$\begin{array}{c}\text { LEVEL } \\
\text { 01-03 }\end{array}$} & \multicolumn{2}{|c|}{$\begin{array}{c}\text { LEVEL } \\
\text { 04-06 }\end{array}$} & \multicolumn{2}{|c|}{$\begin{array}{c}\text { LEVEL } \\
\text { 07-09 }\end{array}$} & \multicolumn{2}{|c|}{$\begin{array}{c}\text { LEVEL } \\
10-12\end{array}$} & \multicolumn{2}{|c|}{$\begin{array}{c}\text { LEVEL } \\
13-17\end{array}$} & \multicolumn{2}{|c|}{ TOTAL } & & & \\
\hline & $\mathbf{M}$ & $\mathbf{F}$ & $\mathbf{M}$ & $\mathbf{F}$ & $\mathbf{M}$ & $\mathbf{F}$ & M & $\mathbf{F}$ & M & $\mathbf{F}$ & M & $\mathrm{F}$ & & & \\
\hline ADO EKITI & 38 & 25 & 94 & 158 & 143 & 355 & 86 & 74 & 25 & 93 & 386 & 705 & 1091 & 55 & 5.7 \\
\hline $\begin{array}{c}\text { EFON } \\
\text { ALAAYE }\end{array}$ & 70 & 54 & 103 & 185 & 130 & 143 & 30 & 30 & 20 & 16 & 353 & 428 & 781 & 82 & 4.1 \\
\hline $\begin{array}{l}\text { EKITI } \\
\text { EAST }\end{array}$ & 108 & 158 & 289 & 275 & 250 & 274 & 19 & 48 & 14 & 17 & 680 & 772 & 1452 & 88 & 7.6 \\
\hline $\begin{array}{c}\text { EKITI S. } \\
\text { WEST }\end{array}$ & 128 & 134 & 115 & 242 & 177 & 302 & 64 & 72 & 12 & 32 & 496 & 782 & 1278 & 63 & 6.7 \\
\hline $\begin{array}{l}\text { EKITI } \\
\text { WEST }\end{array}$ & 75 & 146 & 166 & 340 & 246 & 362 & 68 & 40 & 27 & 8 & 582 & 896 & 1478 & 65 & 7.7 \\
\hline EMURE & 45 & 88 & 48 & 90 & 86 & 100 & 70 & 110 & 203 & 117 & 452 & 505 & 957 & 90 & 5.0 \\
\hline GBONYIN & 109 & 111 & 158 & 188 & 234 & 321 & 134 & 137 & 15 & 14 & 650 & 771 & 1421 & 84 & 7.4 \\
\hline IDO/OSI & 129 & 114 & 201 & 195 & 176 & 253 & 42 & 50 & 24 & 35 & 572 & 647 & 1219 & 88 & 6.4 \\
\hline IJERO & 211 & 120 & 150 & 190 & 108 & 197 & 79 & 125 & 51 & 55 & 599 & 687 & 1286 & 87 & 6.7 \\
\hline IKERE & 110 & 98 & 100 & 166 & 160 & 397 & 38 & 78 & 15 & 33 & 423 & 772 & 1195 & 55 & 6.3 \\
\hline IKOLE & 203 & 164 & 136 & 183 & 164 & 221 & 83 & 64 & 60 & 77 & 646 & 709 & 1355 & 91 & 7.1 \\
\hline $\begin{array}{c}\text { ILEJEMEJ } \\
\mathbf{E}\end{array}$ & 83 & 33 & 98 & 174 & 127 & 132 & 36 & 25 & 13 & 6 & 357 & 370 & 727 & 96 & 3.8 \\
\hline $\begin{array}{c}\text { IRE/IFELO } \\
\text { DUN }\end{array}$ & 62 & 57 & 192 & 212 & 192 & 386 & 67 & 128 & 25 & 59 & 538 & 842 & 1380 & 64 & 7.2 \\
\hline ISE/ORUN & 71 & 73 & 106 & 125 & 115 & 194 & 100 & 145 & 24 & 48 & 416 & 585 & 1001 & 71 & 5.2 \\
\hline MOBA & 124 & 36 & 150 & 210 & 172 & 168 & 54 & 26 & 16 & 10 & 516 & 450 & 966 & 115 & 5.1 \\
\hline OYE & 131 & 45 & 168 & 240 & 188 & 259 & 84 & 37 & 49 & 30 & 620 & 611 & 1231 & 101 & 6.4 \\
\hline $\begin{array}{l}\text { L.G.AGEN } \\
\text { CIES }\end{array}$ & 9 & 4 & 30 & 49 & 50 & 81 & 34 & 17 & 10 & 7 & 133 & 158 & 293 & 84 & 1.5 \\
\hline $\begin{array}{c}\text { SUB- } \\
\text { TOTAL } \\
\end{array}$ & $\begin{array}{c}170 \\
6 \\
\end{array}$ & $\begin{array}{c}146 \\
0\end{array}$ & 2304 & 3222 & $\begin{array}{c}271 \\
8 \\
\end{array}$ & 4145 & $\begin{array}{c}108 \\
8\end{array}$ & $\begin{array}{c}120 \\
6 \\
\end{array}$ & 603 & 657 & $\begin{array}{c}841 \\
9 \\
\end{array}$ & $\begin{array}{c}106 \\
90 \\
\end{array}$ & $\begin{array}{c}1910 \\
9 \\
\end{array}$ & 79 & 100 \\
\hline $\begin{array}{l}\text { \% SUB- } \\
\text { TOTAL }\end{array}$ & 8.9 & 7.6 & 12.1 & 16.9 & 14.2 & 21.7 & 5.7 & 6.3 & 3.2 & 3.4 & 44.1 & 55.9 & 100 & & \\
\hline TOTAL & \multicolumn{2}{|c|}{3166} & \multicolumn{2}{|c|}{5526} & \multicolumn{2}{|c|}{6863} & \multicolumn{2}{|c|}{2294} & \multicolumn{2}{|c|}{1260} & \multicolumn{2}{|c|}{19109} & & & \\
\hline \% TOTAL & \multicolumn{2}{|c|}{16.6} & \multicolumn{2}{|c|}{28.9} & \multicolumn{2}{|c|}{35.9} & \multicolumn{2}{|c|}{12.0} & \multicolumn{2}{|c|}{6.6} & \multicolumn{2}{|c|}{100} & & & \\
\hline $\begin{array}{c}\text { SEX } \\
\text { RATIO \% } \\
\end{array}$ & \multicolumn{2}{|c|}{116} & \multicolumn{2}{|c|}{72} & \multicolumn{2}{|c|}{66} & \multicolumn{2}{|c|}{90} & \multicolumn{2}{|c|}{92} & \multicolumn{2}{|c|}{79} & & & \\
\hline
\end{tabular}

The Tablel above reveals the Percentage Distribution of the grand total of personnel statistics by grade level in relation to their respective local government. It represents the percentage distributions of the Sub-Total and Total personnel in all the local governments and agencies in relation to their grade levels. Sex ratio by local government and cadre is also shown on the table. 
In the same vein, the Percentage Sub-Total in Table 1 gives percentage distribution of personnel by grade level and gender across all the Local Governments. It shows that the percentage difference between male and female on grade level (07-09) was relatively high (14.22\% and 21.69\%). This means that there were more female staffers on grade level (07-09) than male in the Local Government service of Ekiti State. It also indicates that more female personnel were in the Local Government service in Ekiti State generally as portrayed by the values $\mathbf{4 4 . 0 6 \%}$ and $\mathbf{5 5 . 9 4 \%}$ for male and female respectively on the overall Percentage SubTotal. In like manner, Sex ratios by local government and cadres show that there were excess of male over female staffers in major local government councils and cadres. The General/ Over-all Sex ratio indicates 79 males per 100 female staffers on cadres in the local government system. The reason for more female in the Local Government might be as a result of the nature of the jobs which tends to be more favoured for women than men. It could also signify that more men were moving out of the service for greener pasture. The Percentage total shows that more personnel (35.92\%) were on grade level (07-09) while only $\mathbf{1 6 . 5 7 \%}$ were on grade level (01-03). The reason for the shortage of staff in the lowest cadre could be as a result of lack of recruitment exercise in the recent time as those formerly occupied the cadre had been promoted.

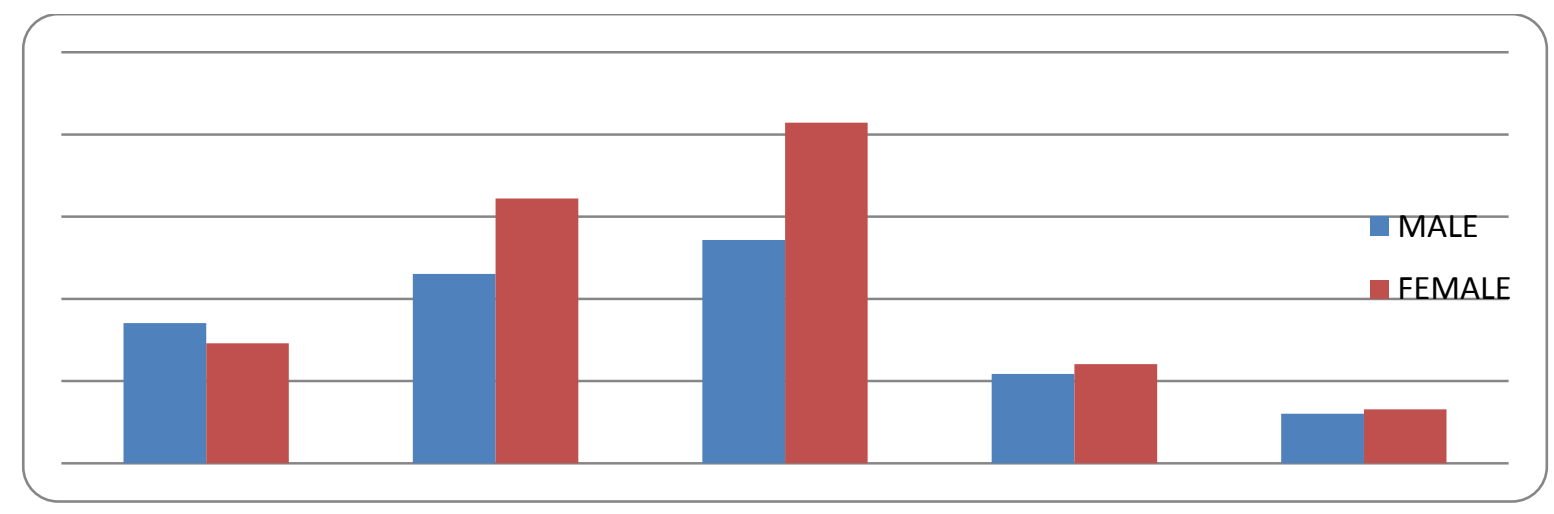

Fig.1. Bar-Chart showing Personnel by Grade Level and Sex

Fig. 1 above, shows the numerical relationship between male and female in the Ekiti State Local Government System. Apart from Grade Level (01-03), all other cadres obviously reveal more female than male. Grade levels 04-09, reveals that the number of female staffers was more than two-third of their male counterpart. This clearly shows the gender imbalance in the system.

\subsection{Data Analysis}

\subsubsection{Using chi-square test to test independency between variables}

\section{Required to test:}

$\boldsymbol{H}_{\mathbf{0}}$ : Independence between number of personnel cadre by cadre and Local Governments in posts

$\boldsymbol{H}_{1}$ : No independence between number of personnel cadre by cadre and Local Governments in posts

Significant Level: $5 \%$

Test Statistic: $x^{2}=\sum_{1}^{r} \sum_{1}^{c}\left(\frac{\left(o_{i j-} E_{i j}\right)^{2}}{E_{i j}}\right)$; 
Table 2. Bar-Chart showing Personnel by Grade Level and Sex

\begin{tabular}{|c|c|c|c|c|c|c|c|c|c|c|}
\hline \multirow{3}{*}{ LOCAL GOVT } & \multicolumn{10}{|c|}{ GRADE LEVEL } \\
\hline & \multicolumn{2}{|c|}{ LEVEL01-03 } & \multicolumn{2}{|c|}{ LEVEL04-06 } & \multicolumn{2}{|c|}{ LEVEL07-09 } & \multicolumn{2}{|c|}{ LEVEL10-12 } & \multicolumn{2}{|c|}{ LEVEL13-17 } \\
\hline & OBS & EXP & OBS & EXP & OBS & EXP & OBS & EXP & OBS & EXP \\
\hline ADO EKITI & 63 & 180.76 & 252 & 315.50 & 498 & 391.83 & 160 & 130.97 & 118 & 71.94 \\
\hline EFON ALAAYE & 124 & 129.40 & 288 & 225.85 & 273 & 280.50 & 60 & 93.76 & 36 & 51.50 \\
\hline EKITI EAST & 266 & 240.57 & 564 & 419.89 & 524 & 521.49 & 67 & 174.31 & 31 & 95.74 \\
\hline EKITI S. WEST & 262 & 211.74 & 357 & 369.58 & 479 & 458.99 & 136 & 153.42 & 44 & 84.27 \\
\hline EKITI WEST & 221 & 244.88 & 506 & 427.41 & 608 & 530.82 & 108 & 177.43 & 35 & 97.46 \\
\hline EMURE & 133 & 158.56 & 138 & 276.75 & 186 & 343.71 & 180 & 114.89 & 320 & 63.10 \\
\hline GBONYIN & 220 & 235.43 & 346 & 410.93 & 555 & 510.35 & 271 & 170.59 & 29 & 93.70 \\
\hline IDO/OSI & 243 & 201.97 & 396 & 352.51 & 429 & 437.80 & 92 & 146.34 & 59 & 80.38 \\
\hline IJERO & 331 & 213.07 & 340 & 371.89 & 305 & 461.87 & 204 & 154.38 & 106 & 84.80 \\
\hline IKERE & 208 & 197.99 & 266 & 345.57 & 557 & 429.18 & 116 & 143.46 & 48 & 78.80 \\
\hline IKOLE & 367 & 224.50 & 319 & 391.84 & 385 & 486.65 & 147 & 162.67 & 137 & 89.35 \\
\hline ILEJEMEJE & 116 & 120.45 & 272 & 210.24 & 259 & 261.10 & 61 & 87.28 & 19 & 47.94 \\
\hline IRE/IFELODUN & 119 & 228.64 & 404 & 399.07 & 578 & 495.63 & 195 & 165.67 & 84 & 90.99 \\
\hline ISE/ORUN & 144 & 165.85 & 231 & 289.47 & 309 & 359.51 & 245 & 120.17 & 72 & 66.00 \\
\hline MOBA & 160 & 160.05 & 360 & 279.35 & 340 & 346.94 & 80 & 115.97 & 26 & 63.70 \\
\hline OYE & 176 & 203.95 & 408 & 355.98 & 447 & 442.11 & 121 & 147.78 & 79 & 81.17 \\
\hline L.G.AGENCIES & 13 & 48.21 & 79 & 84.15 & 131 & 104.51 & 51 & 34.93 & 17 & 19.19 \\
\hline
\end{tabular}

$x^{2}=2618, \mathrm{df}=64, \mathbf{p}$-value $=2.2 \mathrm{e}^{-16}, \boldsymbol{x}^{2}$ critical $=43.19$.

Decision Rule: Reject $\boldsymbol{H}_{0}$ if $\boldsymbol{x}^{2}>x^{2}$ critical, otherwise, do not reject.

Decision: Since $x^{2}=2618$ is $>x^{2}$ critical $=43.19$, we therefore reject $\boldsymbol{H}_{\boldsymbol{0}}$.

Conclusion: This means that number of personnel in each grade level depends on the Local Government Council in post. The relationships between the number of personnel on each cadre and local governments in post were as a result of certain features of interest that the Local Government had.

\section{Summary of Findings}

The percentage distribution on Table 1 above shows that some Local Governments (Ekiti West, Ekiti SouthWest, Gbonyin, Irepodun/Ifelodun, Ekiti East, and Ijero Local Governments) had more workers than other Local Governments like Efon Alaaye, Emure, Ilejemeje Local Governments etc. It reveals also that more female personnel worked in the Local Governments than their male counterpart. Finding shows as well that number of workers at the lowest cadre (01-03) was lower than other higher cadres were. This shows that no recruitment had been done in recent time to feel vacant positions in the lower cadre. Generally, there were more female staffers in the local Government system in Ekiti state than their male counterpart. It also reveals that there were more female that male staffers across cadres in the system. The reason for this could be as a result of flexibility of the system which favours female more than male. It could also be as result of the fact that some departments like Primary Health Care, Environmental Service and Community Departments are more female friendly by nature of their services and duties. However, there were more male than female personnel in the lowest cadre because of the nature of their jobs as most of it was done manually. It implies that personnel on grade level (01-03) were inadequate to service senior cadres in the system.

Chi-Square test of Independence carried out on Table 2 reveals that the number of personnel in each grade 
level depends on the Local Government in post. The more advantageous a local government is in terms of population, nearness to the capital city, social amenities and years of creation determines the number of personnel to be posted to the local government which customarily determines the number of personnel cadre by cadre.

\section{Conclusion}

According to the findings from the analysis, it is concluded that distribution of workers in the local government system in Ekiti State was not done in strict adherence to the lay down rules but allowed to be influenced by favour-seeking workers. It is also concluded that the nearer a local government to the capital city the more likely the number of workers in the local government. This enables them to reside in the capital city in order to tap socio-economic benefits. It could also be inferred that more personnel are posted to local governments where more socio-economic benefits are accessible regardless of its distance to the capital city. It could be deduced that no general appointment and posting was done in the recent time past to adjust some lopsided distribution of staffers which might be occasioned by staffers exiting the service for one reason or the other in some local governments.

However, it could be concluded that female workers are more than male because of the nature of duties of some departments in the local government service. Generally, there was gender imbalance in the local government service as excess female workers were on each grade level and local government council. Some Local Governments inherited from mother state (Ondo State) where Ekiti State was created also enjoyed more staffers than other Local Governments created along with the creation of the state. It is concluded that junior personnel on grade level (01-03) were inadequate in the system. This was as a result of lack of regular recruitment to fill up vacant positions.

\section{Recommendation}

(1). Local Government Service Commission must ensure strict adherence to the use of personnel estimate while doing posting to eradicate unnecessary influence on posting in order to address unproportionality and lop-sidedness in the distribution of workers.

(2). Government should embark on recruitment of workers in to the lower cadre of the service to make workers available to serve the higher cadres, and also to save the system from "missing cadres". This will ensure maintaining the pyramidal shape of staff strength of a normal corporate organisation.

(3). Gender sensitivity should be encouraged to avoid domination of a particular sex.

(4). Transportation problem and other social amenities deficits should be addressed to ease conveyance of workers to their working place at low cost. This will encourage workers to live at any part of the state no matter how far or near to their place of work.

(5). Biometric payment system that is on-going should be maintained and needed adjustment carried out where necessary to encourage unhindered access to any form of payment like cooperative society or other financial issues. This alone will go a long way in addressing the problem associated with staff seeking for transfer or dishonouring posting.

(6). Offices in all the Local Government Secretariats should be made conducive for service to avoid concentration of staff in Local Government with better facilities and good conditions of service.

\section{References}

[1] Achimugu Hassan, Stephen Makoji Roberts and Agboni Uyo Joy. Local Government Service Delivery in Nigeria: An Empirical Comparison of Government Efforts and the People's Expectations, Journal of 
MCSER-CEMAS-Sapienza University of Rome; 2013.

[2] Agnihotri, S. B. Sex Ratio Patterns in the Indian Population: A Fresh Exploration, New Delhi: Sage; 2000.

[3] Akpomuvire Mukoro. The Impact of Rules and Regulations on Personnel Performance in the Unified Local Government Service of Nigeria. Journal of Social Sciences; 2003

[4] Bello-Imam I.B. Local Government in Nigeria Evolving Third-Tier of Government, Heinemann Educational Books (Nigeria), 1996.

[5] Cheema, G. Shabbir and Rondinelli, D.A.(eds). Decentralization and Development: Policy Implementation in Developing Countries. Beverly Hills: Sage, 1984.

[6] Federal Government. The Constitution of the Federal Republic of Nigeria 1999(Amendment) VOL II, Federal Government Printer, Lagos, 2001; 120, 140, 144-145.

[7] Federal Republic of Nigeria. Approved Scheme of Service for local government employees in Nigeria, Federal Republic of Nigeria, 1988

[8] http://www.statisticalassociates.com/assumptions.pdf

[9] Jide Ibietan, Peter Ndukwe. Local Government Administration in Nigeria and the Localist Theory: Exploring the Nexus, Journal of Research Academy of Social Scientist, 2014

[10] Murray R. Spiegel and Larry J. Stephens: Schaum's Outlines Statistics, McGraw Hill $3^{\text {rd }}$ Edition, 2008; 261-276.

[11] Ogunna A.E.C. A handbook on Local Government in Nigeria, Versatile Publisher, 1996

[12] Olu Ale. Practical Administration and the Challenges for Officers in the Public Service of Nigeria, Dimeji Ojo Printers, $1^{\text {st }}$ Edition, 2011, xxv, xxvii-xxviii, 216-278.

[13] Sharma O. P. and Haub C. "Sex ratio at birth begins to improve in India", Population reference bureau; 2008 (http://www.prob.org/Atricles/2008/indiasexratio.aspx).

[14] Sheldon M. Ross. Introduction to Probability and Statistics for Engineers and Scientists. Elsevier Academic Press, $3^{\text {rd }}$ Edition 2004; 185,499-500

[15] Stella Chioma, Opara. Local Government Service Commission and challenges of Local Government Autonomy in Nigeria: An Evaluation. Journal of IIST 2015; 46- 49

[16] Thompson, W. Delivering Service in Nigeria: A Roadmap. Office of Public Service Reform: United Kingdom 2004.

[17] Wilson, K. and Hardy, I.C.W. "Statistical analysis of sex ratios: an introduction", and Sex ratios: Concepts and Research Methods 2002; pp 48-92 ISBN 0521665787.

\section{Authors' Profiles}

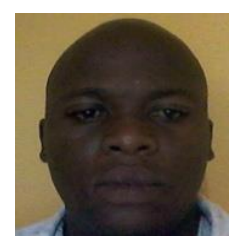

Olaniyan Joseph Olawale (born December 12, 1980) is a Civil Servant, Data Analyst and Lecturer. He is the current Sectional-head of Research and Statistics, Local Government Service Commission, Ekiti State, Nigeria.

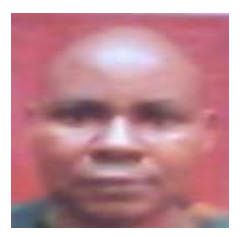

Ademuyiwa A. Justus (born) is a Civil Servant, Data Analyst and Lecturer, Educator and Farmer. He is the current Head of Department of Statistics, Federal Polytechnic, Ile-Oluji, Ondo State Nigeria. 
How to cite this paper: Olaniyan Joseph Olawale, Ademuyiwa A. Justus,"Comparative Analysis of Personnel Distributions in the Local Government Service in Ekiti-State, Nigeria, for Service Delivery", International Journal of Mathematical Sciences and Computing(IJMSC), Vol.5, No.2, pp.44-53, 2019.DOI: 10.5815/ijmsc.2019.02.04 